\title{
Mata ciliar, conservação e sustentabilidade. Fundamentos de sua importância para o Semiárido paraibano: Estudo de caso no alto curso do Rio Paraíba.
}

\author{
Ciliary forest, conservation and sustainability, foundations of importance for the semi- \\ arid region of Paraiba: a case study in the upper reaches of the Paraíba River.
}

\author{
CORREIA ${ }^{1}$, I. M. G.; SOUZA², B. H.; MOURA ${ }^{3}$, D. C.; SOUZA ${ }^{4}$, Y. G. \\ iluli.correia@gmail.com;
}

\begin{abstract}
Resumo
A demanda por recursos naturais, especialmente hídricos, para fins sociais e econômicos é crescente em toda a Terra. No Brasil, o plano de integração das bacias do rio São Francisco carrega a esperança de trazer segurança hídrica para diversas cidades no semiárido nordestino. No entanto, a execução de sua obra tem apresentado grandes modificações em seu espaço natural. Assim, a presente pesquisa tem como objetivo, ressaltar a importância da aplicação da legislação ambiental no âmbito da proteção e plantio de matas ciliares ao longo dos trechos do alto curso do Rio Paraíba, que por sua vez, será perenizado com a conclusão das obras da transposição do rio São Francisco. Com isso, utilizou-se de imagens de satélites provenientes do sensoriamento remoto, bem como de radar, nesse caso, imagens SRTM, no qual pôde-se constatar que, o relevo da bacia do alto curso do rio Paraíba possui cotas hipsométricas que variam de $231 \mathrm{~m}$ a $1200 \mathrm{~m}$ de altitude; e declividade com valores que variam entre $0^{\circ}$ a $64,9^{\circ}$. Somado a isso, foi identificado também que o uso indiscriminado dos remanescentes ribeirinhos tem afetado o equilíbrio ecossistêmico da área estudada, especialmente o manejo inadequado das matas ciliares e dos solos. Conclui-se que a Constituição Federal dispõe de funções legais que asseguram esses ambientes a partir do Novo Código Florestal, que define estes como área proteção permanente e o seu uso inadequado fere os preceitos apresentados pela mesma.
\end{abstract}

Palavras-chave: Recursos naturais; legislação ambiental; Constituição Federal.

\begin{abstract}
Demand for natural resources, especially water, for social and economic purposes is increasing across the Earth. The integration plan for the São Francisco river basins carries the hope of bringing water security to several cities in the Brazilian semiarid. However, the execution of the integration plan has presented great modifications in its natural space. Thus, the present research aims to highlight the importance of environmental legislation in the scope of protection and planting of riparian forests along the stretches of the upper course of the Paraíba River that will be perpetuated with the completion of the works of transposition of the São Francisco River. With this, it was possible to verify that the relief of the upper basin of the Paraíba river has hypsometric dimensions that vary from 758 to 3937 feet of altitude; and slope with values ranging from $0^{\circ}$ to $64.9^{\circ}$. In addition, it was also identified that the indiscriminate use of riparian remnants has affected the ecosystem balance of the studied area, especially the inadequate management of riparian forests and soils. It was concluded that the Brazilian Federal Constitution has legal functions that ensure these environments from the New Forest Code, which defines these as permanent protection areas and its inappropriate use violates the precepts presented by the same.
\end{abstract}

Keywords: Natural resources; environmental legislation; Brazilian Federal Constitutio.

\footnotetext{
${ }^{I}$ Iluliane Maria Gadelha Correia, Departamento de Geografia/Laboratório de Estudos sobre Política, Território e Cultura, Universidade Federal de Campina Grande, Campinha Grande-PB, Brasil.

${ }^{2}$ Brenda Henrique de Souza, Departamento de Geografia/Unidade Acadêmica de Geografia, Universidade Federal de Campina Grande, Campina Grande-PB, Brasil.

${ }^{3}$ Débora Coelho Moura, Departamentode Geografia, Universidade Federal de Campina Grande, Campina Grande-PB, Brasil.

${ }^{4}$ Yuri Gomes de Souza, Departamento de Geografia/Grupo de Pesquisas de Cartografia, geoprocessamento e Sensoriamento Remoto, Universidade Federal de Campina Grande, Campina Grande-PB, Brasil.
} 


\section{INTRODUÇÃO}

O Nordeste brasileiro convive historicamente com o problema da escassez hídrica, em especial a região conhecida como Semiárido, que abrange a maior parte das regiões do Sertão e do Agreste, tais regiões cobrem aproximadamente $57 \%$ da área total do Nordeste, e apresentam uma precipitação média anual inferior a 800 milímetros.

Em decorrência dessa característica, a vegetação da região é de Caatinga, com plantas adaptadas a falta de água, as quais são encontradas em diferentes níveis de degradação, nas regiões próximas às áreas urbanas, como cidades e povoados, em consequência do desmatamento aleatório (MINISTÉRIO DA INTEGRAÇÃO NACIONAL, 2004; SUASSUNA, 2005; MOURA, 2015).

Diante da vegetação de Caatinga está susceptível a degradação antrópica, ocorre variabilidade climática dessa região, que pode dificultar a regeneração da mesma. Porquanto, em anos de El Niño sofrem com longos períodos de estiagem e as chuvas se reduzem a menos de $300 \mathrm{~mm}$, as quais são mal distribuídas, podendo comprometer a vulnerabilidade social. Por conseguinte, o Projeto Integração do Rio São Francisco visa proporcionar, através de segurança hídrica a melhoria da qualidade de vida da população local (CARVALHO \& OLIVEIRA, 2010, p.46; SOARES 2013).

O Projeto de Transposição do Rio São Francisco, visa perenizar a bacia do Rio Paraíba, no qual abastece principalmente o açude Epitácio Pessoa, o mesmo fornece água para o consumo humano e animal, de cidades médias, como Campina Grande e 19 municípios do entorno. Este açude em sua capacidade máxima de armazenamento, retém aproximadamente 411.686.287 $\mathrm{m}^{3}$, contudo, o volume total para os dias 20/06/2017, confere a $29.911 .187 \mathrm{~m}^{3}$, equivalente a 6,5\%. Isto significa, bem menos em relação à sua capacidade de acumulação (AESA, 2017).

A água é o recurso natural mais vital para o ser humano e extremamente reduzido. $\mathrm{O}$ suprimento de água doce de boa qualidade é essencial para o desenvolvimento econômico, para a qualidade de vida das populações humanas e para a sustentabilidade dos ciclos no planeta. No contexto global atual de baixa disponibilidade de água, ainda existem as disparidades regionais, como no caso do Brasil, onde o Nordeste apresenta uma maior concentração de pessoas e possui restrições hídricas, por isso, é extremamente necessário reduzir os impactos ambientais poluição e degradação do meio, principalmente dos recursos hídricos, que veem implicando em prejuízos a saúde do homem, à sociedade e aos recursos naturais renováveis, são necessárias assim o cumprimento das legislações ambientais 
existentes e realização de medidas mitigadoras passíveis de serem aplicadas na área (ALVES; LIMA; FARIAS, 2012).

Por sua vez, para proteção de cursos de água naturais e artificias, podemos destacar como código regulador para proteção da vegetação e de mata ciliar contra a ação antrópica, o Novo Código Florestal (Lei No 12.651, de 25 de Maio de 2012), que define Área de Preservação Permanente (APP) como uma área protegida, coberta ou não por vegetação nativa, com a função ambiental de preservar os recursos hídricos, a paisagem, a estabilidade geológica e a biodiversidade, facilitando assim o fluxo gênico de fauna e flora, além de proteger o solo e assegurar o bem-estar das populações humanas.

$\mathrm{O}$ artigo $2^{\circ}$ do Código Florestal objetiva proteger a cobertura vegetal, indicando como floresta de preservação permanente, aquelas situadas ao longo dos rios ou de qualquer curso d'água, desse modo, estas não podem ser manejadas de forma a que se elimine toda e qualquer vegetação existente sobre uma área. Ao preserva-la, protege-se o solo dos processos erosivos, preserva-se a fauna e a flora. O primeiro quando tem sua cobertura florestal eliminada sofre modificações em sua estrutura e perde as propriedades físico-químicas capazes de garantir a retenção de água.

Diante desse contexto, a mata ciliar ${ }^{1}$ funciona como um obstáculo natural ao escoamento das águas, diminuindo seu impacto direto no solo, evitando assim que as partículas sólidas sejam arrastadas e depositadas no leito dos rios, assoreando-os, sendo de fundamental importância para o equilíbrio do meio.

É necessário assim, em uma obra como a transposição das águas do Rio São Francisco, que sejam considerados nas áreas de entorno dos reservatórios, canais e trechos naturais dos rios, os parâmetros ambientais e sociais, em especial das matas ciliares que diminuem a evaporação da água sendo dessa forma de extrema relevância a sua conservação, que são vulneráveis à ação antrópica em cada área impactando na qualidade e quantidade da água que será transposta, promovendo além disso a manutenção, conservação e regeneração do bioma Caatinga.

Diante dessa conjuntura, essa pesquisa tem como objetivo, ressaltar a importância da aplicação da legislação ambiental no âmbito da proteção e plantio de matas ciliares ao longo

\footnotetext{
1 Vegetação que margeia os corpos hídricos e os reservatórios de água naturais ou não, sendo essencial a manutenção das fontes de água e da biodiversidade. Apresentam em sua composição, espécies típicas, resistentes ou tolerantes ao encharcamento ou excesso de água no solo. Dentre suas inúmeras funções destacam-se: ser habitat, refúgio e alimento para fauna, atuar como corredores ecológicos, manter o microclima e qualidade da água e conter os processos erosivos (CHAVES, 2009, MINISTERIO DA INTEGRAÇÃO NACIONAL, 2010).
} 
dos trechos do alto curso do Rio Paraíba, que por sua vez, será perenizado com a conclusão das obras da transposição do rio São Francisco.

\section{METODOLOGIA}

2.1 Caracterização da área de estudo

A bacia hidrográfica do rio Paraíba, localiza-se no semiárido paraibano e integra as mesorregiões da Borborema, do Agreste e do Litoral, é a segunda maior bacia hidrográfica do Estado da Paraíba, pois abrange aproximadamente 38\% do seu território (Figura 01). Sua nascente está localizada na Serra do Jabitacá no município de Monteiro, e se estende até a sua foz, no Oceano Atlântico, no município de Cabedelo.

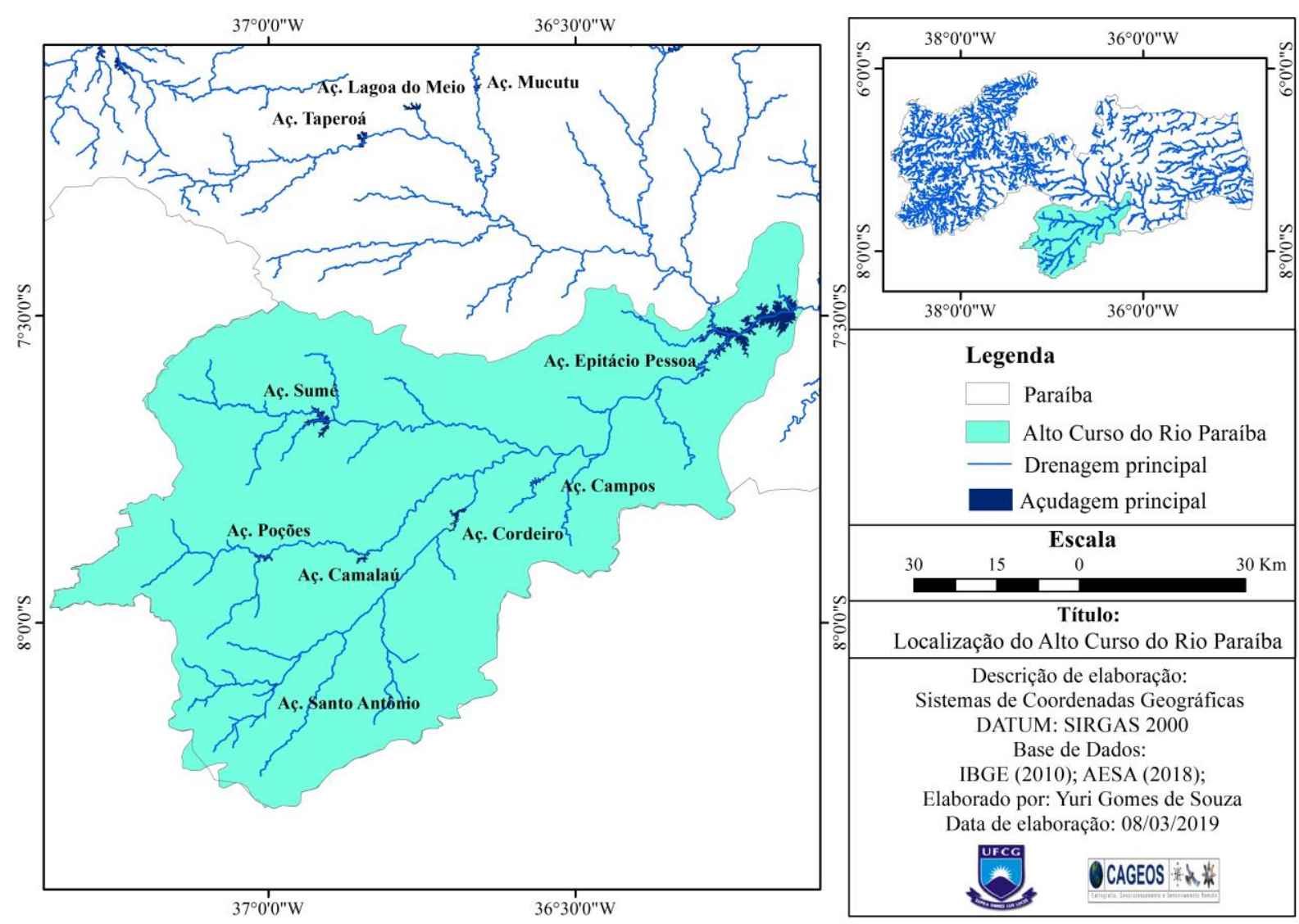

Figura 01: Localização da área de estudo. Fonte: Yuri Gomes de Souza (2019).

O alto curso da bacia do Rio Paraíba é considerado, o setor mais seco do Estado, devido ao seu baixo índice pluviométrico e pela má distribuição das chuvas na região. O uso da terra é caracterizado intensivamente pela prática da agricultura e da pecuária, contudo há também uma grande porção ocupada por vegetação nativa remanescente do Bioma Caatinga (ARAÚJO et al., 2009; MARCUZZO et al., 2012). 
O clima do alto curso do Rio Paraíba, de acordo com possui o clima BSh, que se estende por toda a Borborema Planalto, onde no vale do rio Paraíba, a precipitação anual é de cerca de 400 mm, considerado um dos locais mais secos do Brasil (ALVARES et al., 2014; FRANSCISCO et al., 2015).

Geologicamente possui ocorrência de rochas vulcânicas e plutônicas de idades diversas, com exceção do litoral e região do baixo curso, onde surgem algumas áreas sedimentares, a amplitude altimétrica varia de 0 a 1710 metros, possuindo assim uma geomorfologia, que varia entre o suave ondulado, fortemente ondulado e regiões mais planas no baixo curso (FERREIRA, 2006; MARCUZZO et al., 2012; ANDRADE; NUNES, 2014,).

\subsection{Procedimentos técnicos}

Todos os processos de elaboração cartográfica foram realizados a partir da utilização dos softwares QGis 2.18 de uso livre e gratuito além do Erdas Imagine 2010 e ArcGis 10 ambos licenciados para Laboratório de Cartografia Digital, Geoprocessamento e Sensoriamento Remoto (CAGEOS) dos cursos de Pós- graduação do Centro de Humanidades da Universidade Federal de Campina Grande (UFCG). A descrição das atividades seguem abaixo:

Recorte da Área de Estudo: o recorte foi realizado através da utilização dos arquivos em formato de shapefile da bacia, disponibilizadas pela Agência Executiva de Gestão das Águas do Estado da Paraíba (AESA), e recortada a partir do programa ArcGis 10 (Figura 01).

Processamento da Imagem de Satélite: A imagem utilizada foi do satélite Landsat 8, sensor Operational Land Imager (OLI), com data: 01/07/2018; e ponto/órbita: 215/65. A obtenção da referida imagem se deu de forma gratuita através da plataforma online da United States Geological Survey (USGS), todas as etapas de Processamento Digital de Imagem - PDI foram realizados no software Erdas Imagine, seguindo os seguintes procedimentos:

- Empilhamento

Consistiu na sobreposição das bandas 4 (Vermelho) e 5 (Infravermelho Próximo) do Landsat 8.

- Reprojeção das imagens

A imagem obtida tem como referência espacial o DATUM World Geodetic System (WGS) 1984 UTM Zona Norte, ou seja, ajustadas para o hemisfério Norte. Assim, havendo a necessidade de reprojetar essas para WGS 1984 UTM Zona Sul.

- Cômputo da Reflectância 
A reflectância para o Landsat 8 é calculada através da Equação 01, utilizando os metadados da imagem (USGS, 2018):

$$
\rho \lambda^{\prime}=(\mathrm{M} \rho * \mathrm{Q} \text { cal }+\mathrm{A} \rho) / \operatorname{Cos} \mathrm{Z}
$$

No qual $\rho \lambda$ ' é a refletância planetária, com correção para o ângulo solar. Mp é o fator multiplicativo (disponível no metadados), Ap é o fator aditivo (disponível no metadados) e Qcal os valores de pixel calibrados do produto padrão Quantized (DN).

- Índice de Vegetação Ajustado ao Solo (IVAS)

Para o cálculo do IVAS utilizou-se a seguinte Equação 02, tendo L=0.5 (HUETE, 1988):

$$
I V A S=\frac{(1+\mathrm{L})\left(\rho_{\mathrm{IV}}-\rho_{\mathrm{V}}\right)}{\left(\mathrm{L}+\rho_{\mathrm{IV}}+\rho_{\mathrm{V}}\right)}
$$

Para tanto, o IVAS foi aplicado a essa pesquisa por possuir um fator de ajuste (L), que ameniza eventuais interferências da energia eletromagnética refletida pelo solo, além de considerar a estrutura dos dosséis e morfologia das plantas (PONZONI \& SHIMABUKURO, 2007).

Recorte das áreas de estudo - Buffer: Para geração do Buffer, acessou-se no menu principal "Vetor/ Geoprocessar/ Buffer (s)", escolheu-se a camada vetorial em formato linha do Rio Paraíba, disponibilizada pela AESA (2018), definiu-se o valor da "Distância do buffer" (100 metros) adequado ao sistema de projeção ao projeto, por fim, direcionou-se o local de sair do Buffer.

O recorte foi realizado através do programa ArcGis 10, que utiliza a ferramenta Spatial Analyst Tools - Extraction - Extraction by Mask.

Nessa Ferramenta, foi inserido o arquivo shapefile do Buffer, a imagem completa para recorte, e direcionada o local de saída do produto, assim, tendo o resultado do polígono.

Hipsometria: Elaborado no ArcGis. A partir das propriedades da imagem SRTM, extraída do banco de dados do Brasil, resultante do projeto Topodata, com resolução de $30 \mathrm{~m}$, fornecida pelo Instituto Nacional de Pesquisas Espaciais (INPE), com chapas identificação de 07S375 e 08S375, cobrindo a área de estudo. Para o tratamento desta no ArcGis 10 utilizou-se a opção Simbology $\rightarrow$ Classified, classificando dando cor aos valores hipsométricos. Pôde-se 
constatar os valores de equidistância entre as cotas altimétricas que variaram entre 231 e $1200 \mathrm{~m}$.

Declividade: Elaborado no ArcGis. Para visualização da declividade foi necessário adotar os seguintes procedimento, no ArcGis: Arctoolbox $\rightarrow$ Spacial Analyst Tools $\rightarrow$ Surface $\rightarrow$ Slope $\rightarrow$ Imput (Imagem SRTM da área) $\rightarrow$ Escolheu-se a opção em graus $\rightarrow$ Output (Saída).

Em seguida, em propriedades da imagem fez-se o uso da opção Simbology $\rightarrow$ Classified, classificando e colorindo a imagem para análise. Os valores variam de $0^{\circ}$ a $64,9^{\circ}$. Para a classificação dos tipos de relevo têm-se as classes de relevo plano, suave ondulado, ondulado, moderadamente ondulado, fortemente ondulado, montanhoso e escarpados (EMBRAPA 1979).

Quadro 01: Classificação de relevo de acordo com a declividade

\begin{tabular}{c|c}
\hline Classificação do relevo & Classificação da Declividade $\left(^{\circ}\right)$ \\
\hline Plano & $0^{\circ}$ a $3^{\circ}$ \\
\hline Suave-ondulado & $3^{\circ}$ a $7^{\circ}$ \\
\hline Ondulado & $7^{\circ}$ a $13^{\circ}$ \\
\hline Forte-ondulado & $13^{\circ}$ a $24^{\circ}$ \\
\hline Montanhoso & $24^{\circ}$ a $34^{\circ}$ \\
\hline Forte-montanhoso & $>34^{\circ}$ \\
\hline
\end{tabular}

Drenagem: elaborada no ArgGis 10 a partir da rede de drenagem da base de dados da AESA (2018).

Mapa Pedológico: O mapa temático foi desenvolvido no programa QGis 2.18 a partir da base de dados da Agência Executiva de Gestão das Águas do Estado da Paraíba - AESA (2018), do Serviço Geológico do Brasil -a CPRM (2019) e do Instituto Brasileiro de Geografia e Estatística - IBGE (2010).

Estudo de Campo: O estudo de campo foi realizado com a finalidade de validar as informações obtidas através dos mapeamentos, corroborando assim a eficiência do mapeamento Nessa atividade foram utilizadas as seguintes ferramentas: máquina fotográfica digital e um GPS da marca Garmim eTREX10 para registros das coordenadas, aplicativo Google Earth foi usado como um facilitador para analisar áreas de acesso e visitas. 


\section{RESULTADOS E DISCUSSÕES}

\subsection{Transposição do Rio São Francisco}

Toda grande obra, pode vir a gerar impactos negativos ao meio ambiente, e não poderia ser diferente com Projeto de Integração do Rio São Francisco, com Bacias Hidrográficas do Nordeste Setentrional, cientes disso, foram elaborados o Relatório de impacto Ambiental, que trazem recomendações destinadas a evitar, mitigar ou compensar seus possíveis impactos negativos e fortalecer os benefícios sociais e ambientais, que o empreendimento pode vir trazer para a região.

Aqui, destaca-se um dos impactos negativos, que vem a ser ocasionado e intensificado na construção desse projeto, no qual segundo o Relatório de Impacto Ambiental (RIMA) poderá ocorrer perda e fragmentação, no entorno da obra de 430 hectares de áreas, com vegetação nativa e de hábitats de fauna terrestre ${ }^{2}$, isso abrange especialmente as áreas onde foram construídos os canais abertos e túneis. Nestas áreas, onde foram colocadas máquinas, que escavaram perfis de solo profundos, retirando para isso, toda cobertura vegetal da superfície (Figura: 02 A, B e C) fragilizando o ecossistema natural do bioma Caatinga. Como consequência as águas dos canais abertos, ficam susceptíveis a maiores índices de evaporação, devido à falta de cobertura vegetal nas margens.

Dessa forma é de extrema importância, que sejam realizadas medidas mitigadoras após a conclusão das obras desse projeto.

\footnotetext{
${ }^{2}$ Ocorrerão em função do desmatamento, que será realizado ao longo da faixa onde os canais serão instalados, nas áreas dos reservatórios, canteiros de obras e estradas de acesso e nos locais de extração de terra e pedra. $\mathrm{O}$ desmatamento promovido resultará também na perda de hábitats da fauna e flora terrestre da região. As áreas de Caatinga Arbórea apresentam grande biodiversidade, sendo o lar de animais típicos da região. O corte dessas árvores poderá acarretar perda de animais adultos e filhotes. Além disso, os canais dividirão o ambiente, interferindo no deslocamento de animais (MINISTERIO DA INTEGRAÇÃO, 2004).
} 

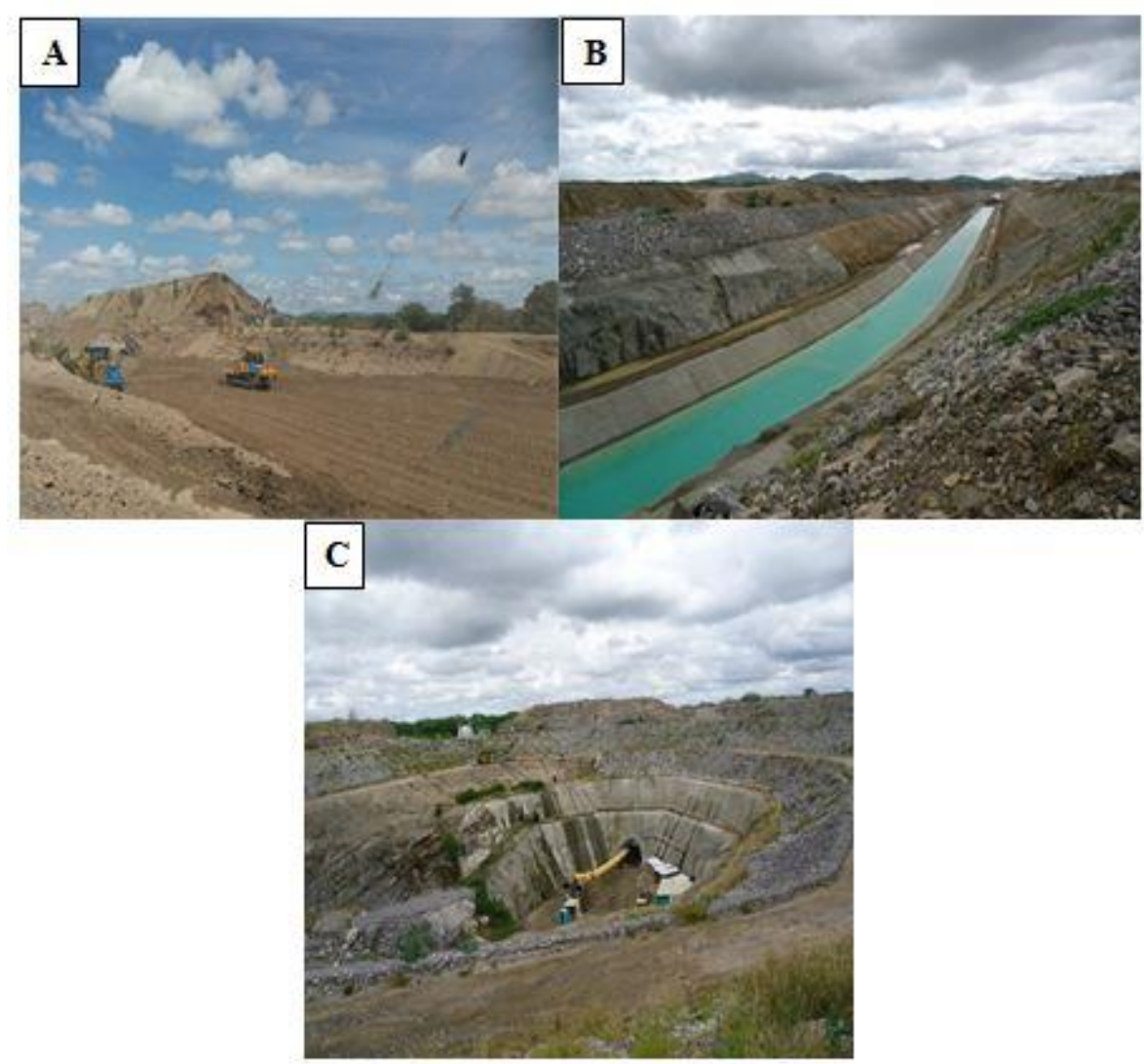

Figura 02: Áreas de perda e fragmentação da vegetação no Canteiro de Obras: A - Galerias Fechadas / BCanais Abertos/ C-Túnel. Fonte: Iluliane Maria Gadelha Correia (2016).

Como propostas mitigadoras, o RIMA apresentado pelo Ministério da interação Nacional (2004) propõe: Restringir o desmatamento ao mínimo necessário para as obras; Reforçar e apoiar a gestão das Unidades de Conservação existentes; Estabelecer pontos de interligação dos ecossistemas, através da cobertura dos canais, em trechos que cruzem áreas de Caatinga Bem-Conservadas, particularmente, aquelas mapeadas como arbórea e Arbustiva Densa, de modo a permitir o fluxo genético entre as populações inicialmente isoladas pelos canais; Realizar o Programa de Educação Ambiental visando à valorização do ecossistema da Caatinga e de conscientização da população para a necessidade de sua preservação; Implantar Unidades de Conservação e outros mecanismos de proteção das áreas de Caatinga ainda preservadas; Realizar o Programa de Apoio às Unidades de Conservação; Realizar o Programa de Monitoramento da Fauna e da Flora.

\subsection{Caracterização física do Alto Curso do Rio Paraíba}

Analisando a Figura 3, foi possivel observar, que o relevo da bacia do alto curso do rio Paraíba possui cotas hipsométricas que variam de 231 a 1200 metros (m) de altitude, com 
predominância de valores entre $300 \mathrm{~m}$ à $600 \mathrm{~m}$ a Nordeste e Sudeste e de $500 \mathrm{~m}$ a $800 \mathrm{~m}$ de Noroeste a Sudoeste.

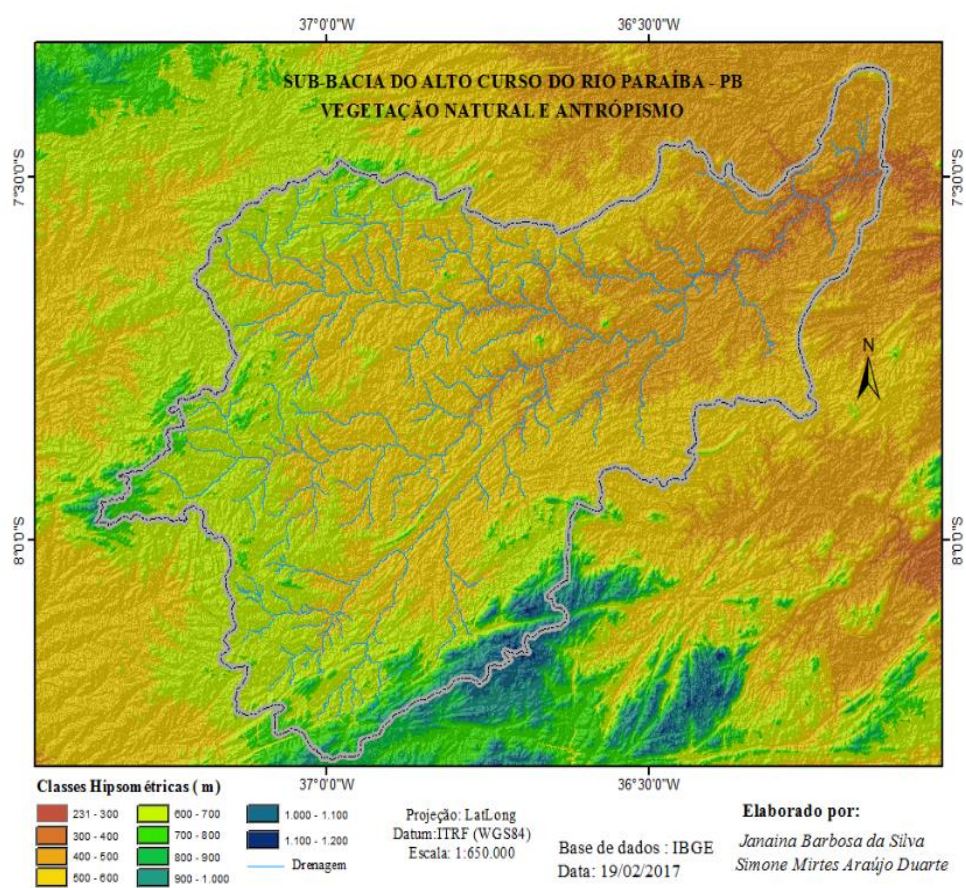

Figura 03: Mapa de Hipsometria e Drenagem do Alto Curso do Rio Paraíba. Fonte: Janaina Barbosa da Silva e Simone Mirtes Araújo Duarte (2017).

Com relação à declividade, constatou-se que na Bacia predomina áreas com declividades entre $0^{\circ}$ a $64,9^{\circ}$, sendo as áreas com declividades superiores a $12,7^{\circ}$ de pouca ocorrência. Identificou-se a predominância dos valores entre $0^{\circ}$ a $6,8^{\circ}$ (Figura 04).

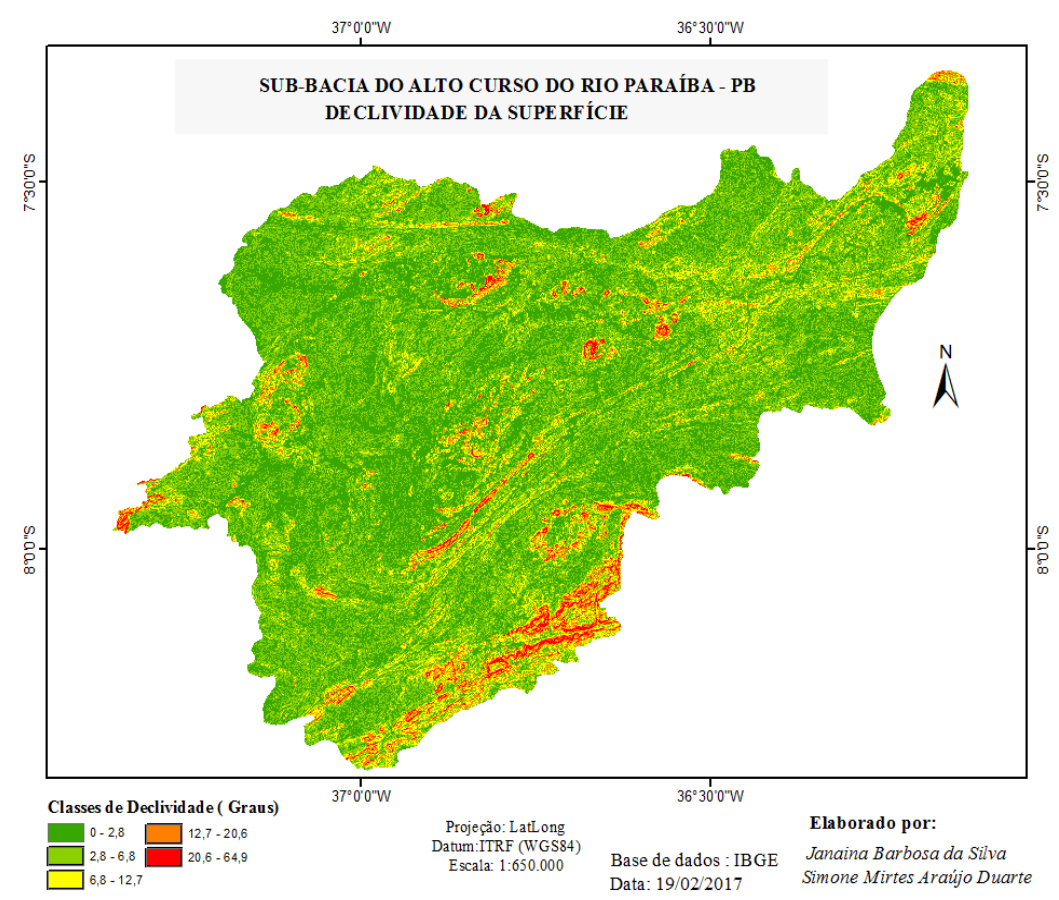

Figura 04: Declividade da superfície do Alto Curso do Rio Paraíba. Fonte: Janaina Barbosa da Silva e Simone Mirtes Araújo Duarte (2017). 
Baseado na tabela de classificação das classes de relevo e declividade da EMBRAPA (1979), verifica-se, que as áreas variam entre $0^{\circ}$ e $1^{\circ}$ correspondem a classe de relevo plano, $3^{\circ}$ a $7^{\circ}$ suave ondulado, de $7^{\circ}$ a $13^{\circ}$ ondulado, de $13^{\circ}$ a $24^{\circ}$ forte ondulado, de $24^{\circ}$ a $34^{\circ}$ amontanhoso e $>34^{\circ}$ forte- montanhoso, (conforme o apresentado no Quadro 01, nos procedimentos técnicos) sendo os dois últimos de menores predominâncias.

Ao correlacionar o mapa hipsométrico com a declividade tem-se, que o relevo da bacia é predominantemente suave ondulado ao fortemente ondulado, nas áreas com declividade entre $0^{\circ}$ aos $12,7^{\circ}$ e estão associadas às áreas de hipsometria, que variam dos $231 \mathrm{~m}$ aos $600 \mathrm{~m}$ de altitude. As áreas, com maior movimentação do relevo possuem declividades superiores a $12,7^{\circ}$ estão associadas a altitudes, que variam dos $600 \mathrm{~m}$ aos $1200 \mathrm{~m}$, não se apresentando estes últimos, como uma característica geral da bacia.

A geomorfologia, hipsometria e declividade de uma bacia, refletem diretamente em seu sistema de drenagem (Figura 03). No caso em questão, foi possivel observar a predominância da drenagem dendrítica média, também conhecida como drenagem arborescente, assim denominada devido sua semelhança com a configuração de uma árvore, onde a corrente principal corresponderia ao tronco da árvore, os tributários aos seus ramos e as correntes de menor categoria aos raminhos e folhas, estes se unem formando ângulos agudos de graduações variadas, mas sem chegar nunca ao ângulo reto (CHRISTOFOLETTI, 1980).

Desse modo, pode-se observar a partir da visita in situ a variação o perfil hipsométrico, de acordo com a Figura 04 de cotas com 361m a 997m, e que nestas áreas além dos impactos ocasionados pelas obras da transposição do Rio São Francisco predominam ainda os impactos gerados pelas atividades da população local, como agropecuária, agricultura intensiva, queimadas, desmatamentos entre outros.

Sobre os aspectos pedológicos, observa-se na Figura 05, que ocorre a presença de Luvissolos, Neossolos Litólicos e Flúvicos, e Vertissolos. Sendo a maior predominância de Luvissolos, solos minerais não hidromórficos, com presença de horizonte subsuperficial diagnóstico textural $(\mathrm{Bt})$ imediatamente abaixo de qualquer tipo de horizonte $\mathrm{A}$, ou sob horizonte E, argila de atividade alta e saturação por bases alta, e Neossolos Litólicos, que compreendem solos rasos, onde geralmente a soma dos horizontes sobre a rocha não ultrapassa $50 \mathrm{~cm}$ de expessura, estando associados normalmente a relevos mais declivosos. As limitações ao uso estão relacionadas a pouca profundidade, presença da rocha e aos declives acentuados associados às áreas de ocorrência destes solos. Estes fatores limitam o crescimento radicular, o uso de máquinas e elevam o risco de erosão (EMBRAPA, 2013). 

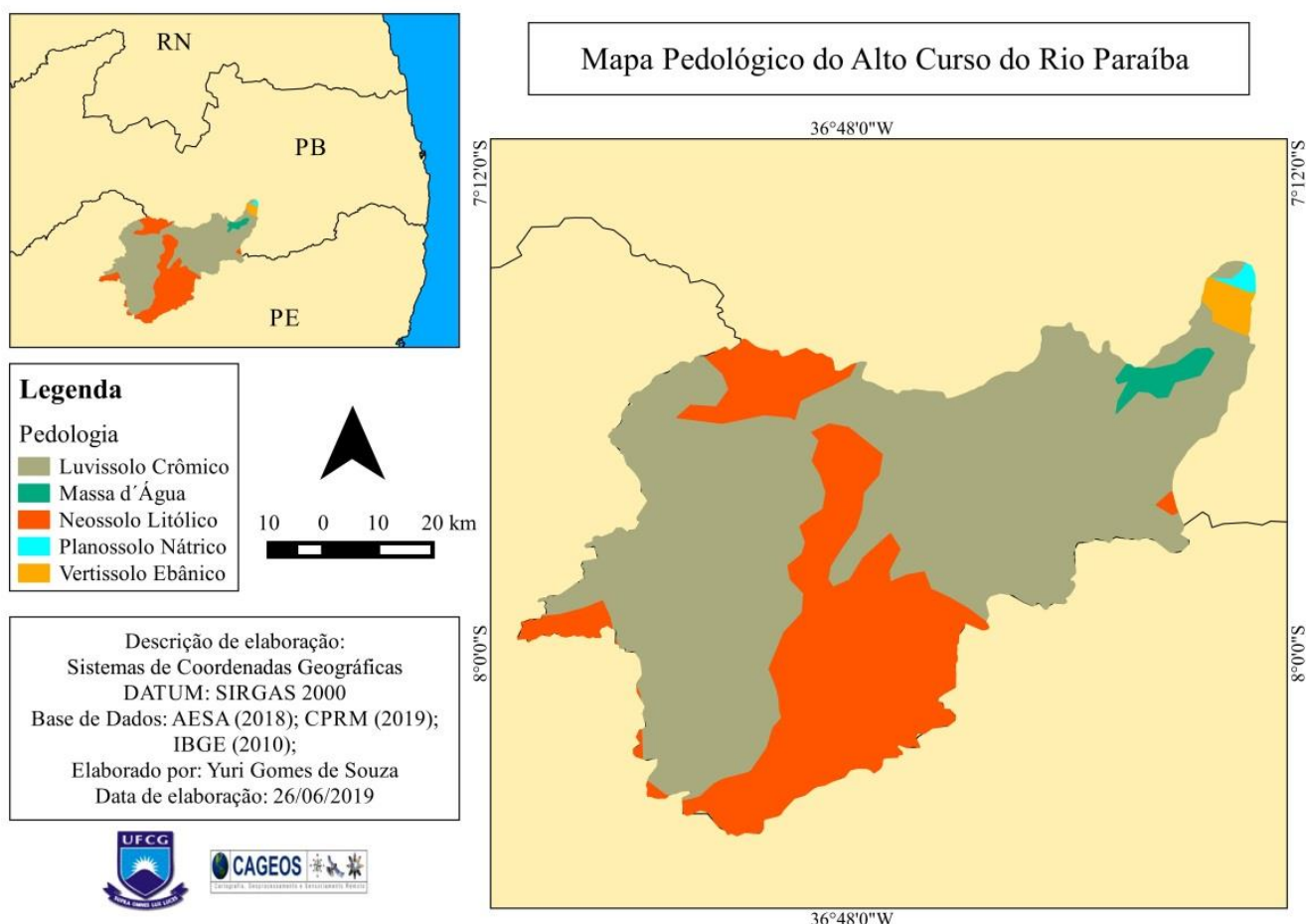

Figura 05: Mapa Pedologico do Alto Curso do Rio Paraíba. Fonte: Yuri Gomes de Souza (2019).

É claramente visível uma maior ocupação antrópica, nas áreas próximas aos cursos dos rios tendo consequência um maior uso do solo, com destaque as proximidades do açude Epitácio Pessoa. Isso se justifica devido à baixa declividade, que varia de 0 a $6,8 \%$, e a maior presença de umidade no solo. Como também os Neossolos Flúvicos, que relatam a história de sedimentação, nas áreas de planície de inundação do rio Paraíba. Estes solos são profundos, com composição média areno-argilosa, hidratado e rico em matéria orgânica (Figura 06).

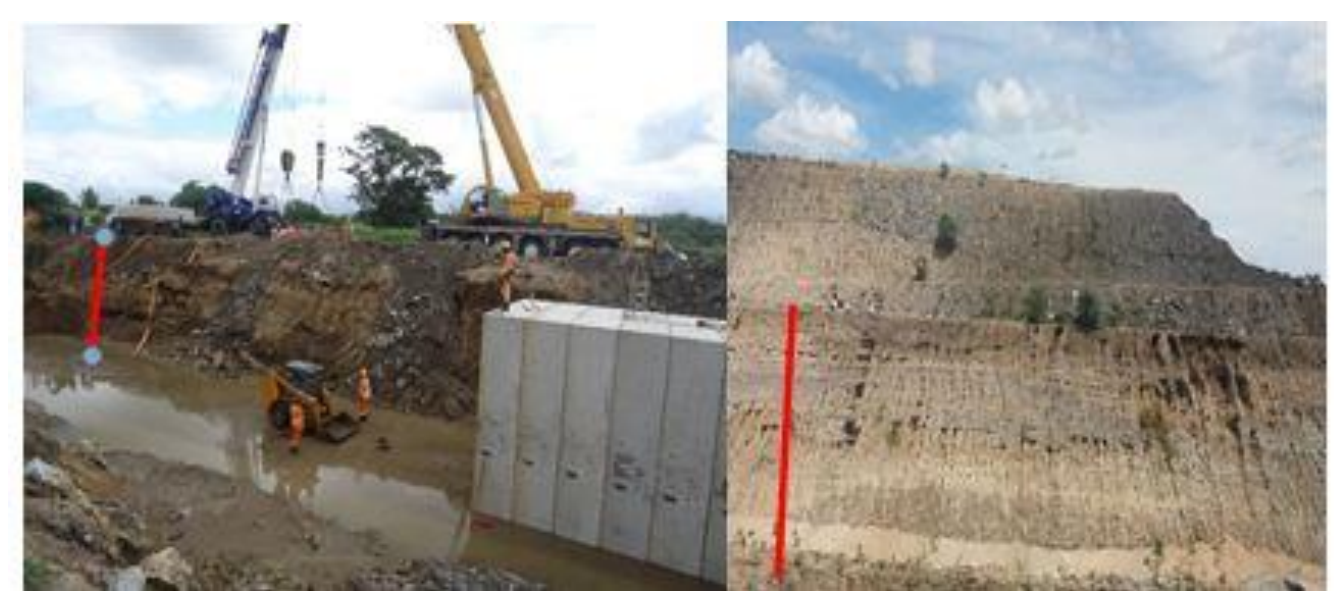

Figura 06: Presença de Neossolos Flúvicos ao longo dos canais. Fonte: Iluliane Maria Gadelha Correia (2016).

Estes solos de deposição, foram oriundos de períodos glaciais e interglaciais, onde estes sedimentos foram sendo depositados, com as mudanças do fluxo caudal do rio em períodos 
quente e seco e quentes e úmidos. Assim, estes podem favorecer um desenvolvimento mais satisfatório da agropecuária, por serem extremamente férteis, principalmente se irrigados, ocasionando assim consequentemente a retirada da vegetação nativa dessas áreas.

É perceptível ainda, que as áreas de maiores declividades de 6,5\% a 64,9\% possuem menores taxas de ocupação antrópica, devido sua alta altitude e por ser consideradas áreas mais secas e de solos mais rasos, com rochas expostas. Esta área é o que dificulta a ocupação humana, no qual possui assim uma vegetação natural mais preservada, possuindo dessa forma uma Caatinga com vegetação mais densa, com presença de vegetação rasteira, herbácea e arbustos densos.

4.3 Mata ciliar, conservação e sustentabilidade: sua importância para estudos do Semiárido Paraibano

Mata ciliar é toda formação vegetal localizada nas margens dos rios, córregos, lagos, represas e nascentes, é considerada pelo Código Florestal Federal (Lei № 12.651, de 25 de Maio de 2012) como área de preservação permanente (APP) possuindo diversas funções ambientais, como aumento da infiltração e armazenamento de água no lençol freático, minimização do processo de erosão e assoreamento, melhoria da qualidade da água e aumento da biodiversidade.

Ainda segundo a Resolução CONAMA 302/2002 a APP deve ocupar a área ao longo de todo o perímetro dos reservatórios podendo em seu $\S 1^{\circ}$ ter os limites da Área de Preservação Permanente ampliados ou reduzidos, observando-se o patamar mínimo de trinta metros, conforme estabelecido no licenciamento ambiental e no plano de recursos hídricos da bacia onde o reservatório se insere, se houver. E de acordo com o $\S 2^{\circ}$ Os limites da Área de Preservação Permanente, previstos no inciso II, somente poderão ser ampliados, conforme estabelecido no licenciamento ambiental, e, quando houver, de acordo com o plano de recursos hídricos da bacia onde o reservatório se insere.

Perante o exposto, e diante dos resultados visualizados a partir do mapeamento do uso e ocupação do solo da APP do Alto Curso do Rio Paraíba (Figura 07), foi possível identificar tanto, áreas classificadas com predominância de Solo Exposto/Área Urbana, Vegetação Herbácea, Vegetação Arbustiva, bem como, Vegetação Arbórea, também foi detectada classe Água em alguns pontos ao longo do curso do rio. 


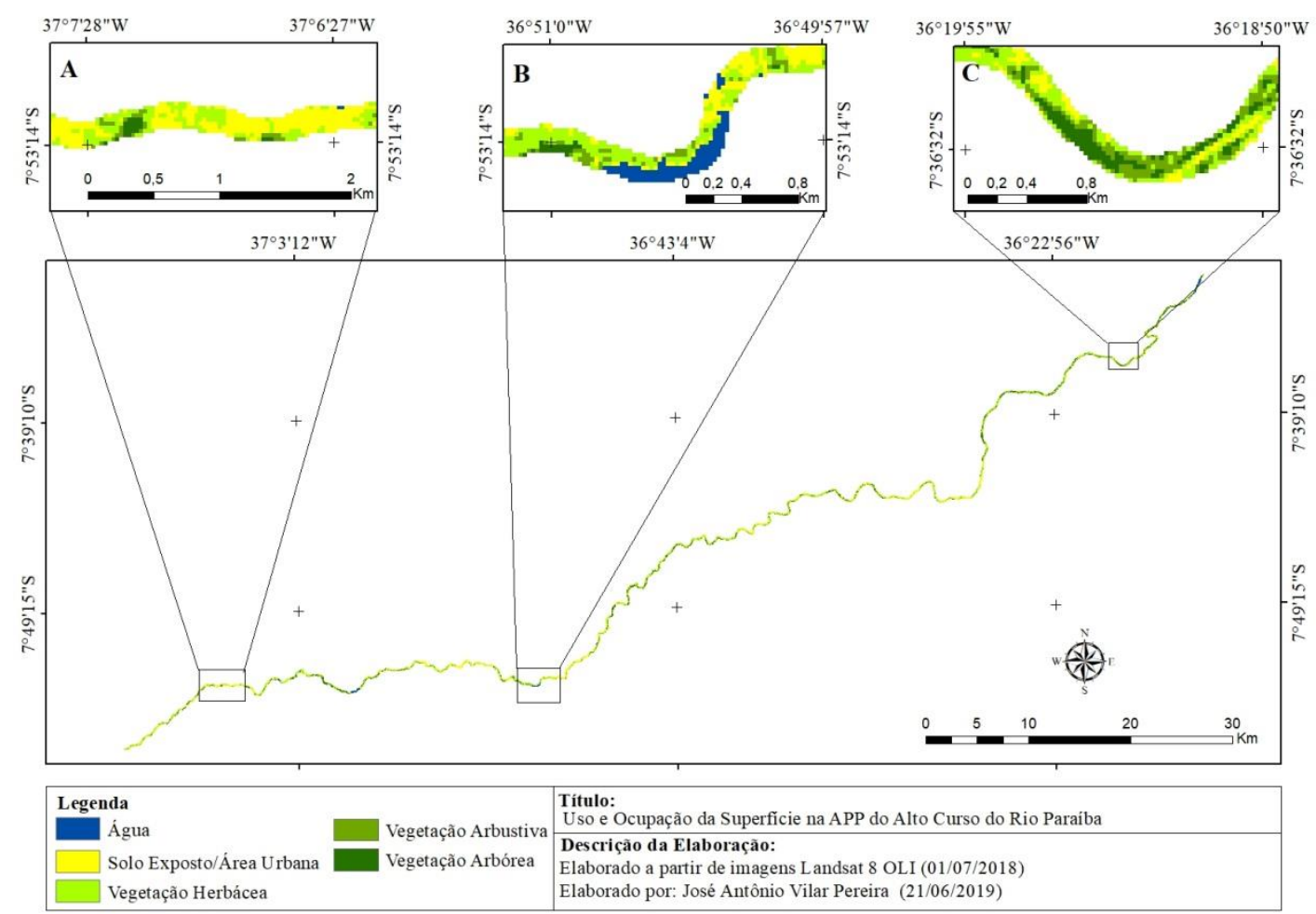

Figura 07: Uso e ocupação da terra na APP do Alto Curso do Rio Paraíba. Fonte: José Antônio Vilar Pereira (2019).

De acordo com a Figura 07 e com os números descritos no Quadro 02, pôde-se constatar maior predominância da classe Vegetação Herbácea e da classe Solo Exporto/Área Urbana, com uma área de aproximadamente $12,2598 \mathrm{~km}^{2}$ e $7,884 \mathrm{~km}^{2}$, respectivamente; já a classe Vegetação Arbustiva aparece com 6,2001 km² e a Vegetação Arbórea com 3,5721 km²; por fim, a classe Água representando $0,9234 \mathrm{~km}^{2}$. Assim, observou-se maior presença de solo exposto e/ou área urbana no recorte, haja vista que sua área representa um valor maior que a classe de Vegetação Arbustiva e da classe Vegetação Arbórea. Logo, isto sinaliza a retirada desta mata ciliar para manutenção de atividades sociais e econômicas desenvolvidas pelo homem no tempo e no espaço.

Quadro 02: Quantificação das classes de Uso e ocupação da terra na APP do Alto Curso do Rio Paraíba.

\begin{tabular}{l|c|c}
\hline \multicolumn{1}{c|}{ Classes } & $\mathbf{K m}^{\mathbf{2}}$ & \% \\
\hline Água & 0,9234 & 2,99 \\
\hline Solo Exposto/Área Urbana & 7,884 & 25,56 \\
\hline Vegetação Herbácea & 12,2598 & 39,75 \\
\hline Vegetação Arbustiva & 6,2001 & 20,10 \\
\hline Vegetação Arbórea & 3,5721 & 11,60 \\
\hline Total & $\mathbf{3 0 , 8 3 9 4}$ & 100 \\
\hline
\end{tabular}


A manutenção e recuperação da vegetação ciliar às margens dos reservatórios, curso natural do rio e nos trechos de canal aberto mitiga muitos impactos negativos, evitando a erosão do solo e assoreamento dos reservatórios e rios, produzindo ainda impactos positivos como diminuição da evaporação, preservação das espécies nativas e abrigo para a fauna da região. Para isso, é necessário conscientizar as pessoas e comunidades beneficiadas pelas obras da transposição e as que se localizam próximos às margens dos rios, canais e reservatórios, tornando-as agentes participativos da conservação e plantio das matas ciliares as margens dos mesmos, preservando a qualidade de vida delas e mantendo a qualidade ambiental da área.

Dessa forma, é necessário ao término das obras, a aplicação da legislação ambiental vigente para conservação desses ecossistemas. O Novo Código Florestal define para área de Área de Preservação Permanente $(\mathrm{APP})^{3}$ em faixas marginais de qualquer curso d'água natural perene e intermitente, excluídos os efêmeros, desde a borda da calha do leito regular sejam reservadas uma largura mínima de 50 (cinquenta) metros, para os cursos d'água que tenham de 10 (dez) a 50 (cinquenta) metros de largura e 100 (cem) metros, para os cursos d'água que tenham de 50 (cinquenta) a 200 (duzentos) metros de largura, como o que é observado na área de estudo.

Quanto a Canais ou Reservatórios artificiais, onde podemos encaixar os canais construídos na transposição, podemos usar no Novo Código Florestal o Art. 62 determinando que para os reservatórios artificiais de água destinados a geração de energia ou abastecimento público que foram registrados ou tiveram seus contratos de concessão ou autorização assinados anteriormente à Medida Provisória no 2.166-67, de 24 de agosto de 2001, a faixa da Área de Preservação Permanente será a distância entre o nível máximo operativo normal e a cota máxima maximorum.

Frente a esse contexto, o açude Epitácio Pessoa (Figura 08), mais conhecido por açude de Boqueirão, principal receptor das águas advindas da transposição do Rio São Francisco vem sinalizando a diminuição de sua capacidade ao longo dos anos por diversos motivos, como desmatamento das matas ciliares, mal uso dos solos, construções de moradias nas margens, construções de barragens particulares a sua montante e a falta de um plano

\footnotetext{
${ }^{3}$ Definida pelo Conselho Nacional do Meio Ambiente (CONAMA) através do Art 3. ${ }^{\circ}$ da Resolução no 302 como a área com largura mínima, em projeção horizontal, no entorno dos reservatórios artificiais, medida a partir do nível máximo normal de: I - trinta metros para os reservatórios artificiais situados em áreas urbanas consolidadas e cem metros para áreas rurais; II - quinze metros, no mínimo, para os reservatórios artificiais de geração de energia elétrica com até dez hectares, sem prejuízo da compensação ambiental; III - quinze metros, no mínimo, para reservatórios artificiais não utilizados em abastecimento público ou geração de energia elétrica, com até vinte hectares de superfície e localizados em área rural (CONAMA, 2002, p.89).
} 
diretor para gestão das águas, mas principalmente pelo assoreamento de sua bacia que fornece uma grande quantidade de sedimentos que são depositados no fundo do açude (BRITO, 2008).

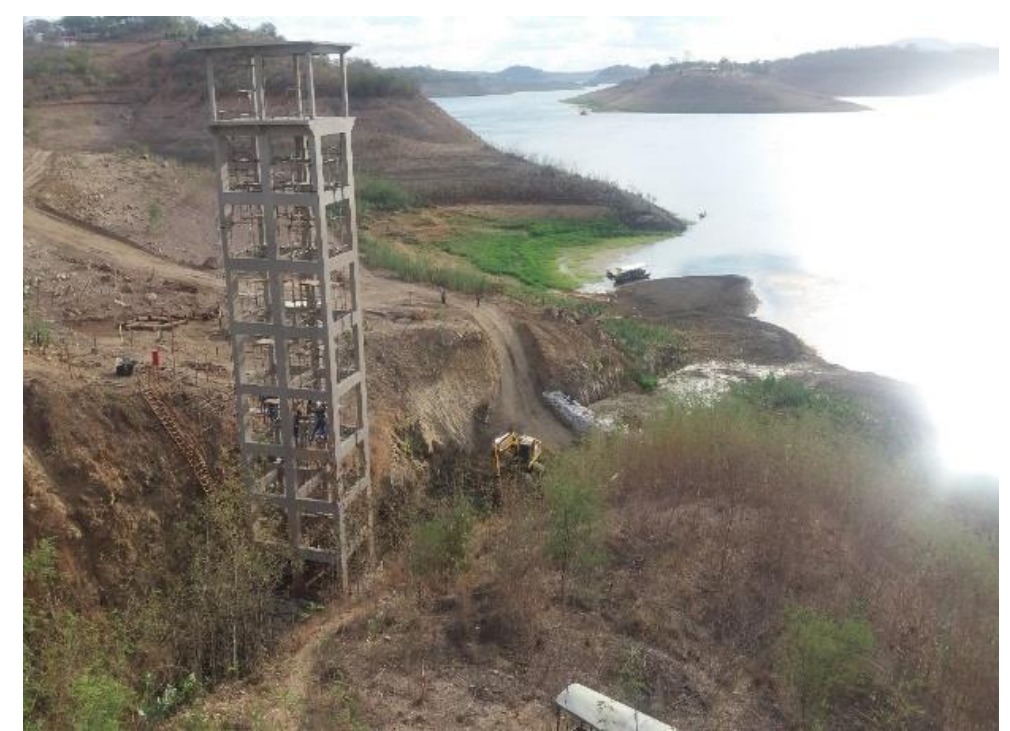

Figura 08: Açude Epitácio Pessoa. Fonte: Iluliane Maria Gadelha Correia (2017).

De acordo com estudos realizados por Morais et al, (2014) com uso de imagens de satélites e técnicas de sensoriamento remoto é visível no entorno do reservatório Epitácio Pessoa, os usos diversos das margens, em contraposição a legislação vigente que assegura a preservação de $30 \mathrm{~m}$ para áreas urbanas e $100 \mathrm{~m}$ para áreas rurais. Foi realizado pelos mesmos autores, uma análise espacial do reservatório em quatro áreas distintas, duas em áreas próximas a área urbana do município de Boqueirão e outras duas no espaço rural. Onde se constatou que, na área urbana de Boqueirão destacam-se construções irregulares e agricultura às margens do reservatório e identificação de áreas de uso da terra de forma ilegal nas proximidades da área urbana consolidada de Boqueirão não respeitando os limites de $30 \mathrm{~m}$.

Que segundo o Código Florestal para as áreas no entorno dos reservatórios d'água artificiais, decorrentes de barramento ou represamento de cursos d'água naturais, o tamanho da faixa é definida na licença ambiental do empreendimento. Já as áreas no entorno das nascentes e dos olhos d'água perenes, qualquer que seja sua situação topográfica, no raio mínimo de 50 (cinquenta) metros. E nas encostas ou partes destas com declividade superior a $45^{\circ}$, equivalente a $100 \%$ (cem por cento) na linha de maior declive.

Assim, de acordo com o Ministério da Integração (2010) o reflorestamento deverá ser realizado após o enchimento dos reservatórios, para que seja possível a irrigação das mudas que serão plantadas, sendo recomendado revegetar as áreas segundo o tipo de solo e o 
teor de umidade do mesmo, levando em consideração as características silviculturas e fisiológicas de cada espécie que for selecionada e implantada, é importante também realizar um levantamento florístico das regiões lindeiras aos reservatórios e áreas degradadas com objetivo de conhecer melhor o local para cada espécie.

Reflorestando as áreas de mata ciliar na área de estudo teremos uma redução do assoreamento e da degradação do meio natural restaurando ainda sua diversidade ambiental. Por serem consideradas de acordo com Castro, Castro \& Souza (2013) zonas ripárias ou zonas-tampão quando estas estão localizadas em áreas de produção agrícolas, previnem ou minimizam a movimentação de sedimentos gerados durante o processo erosivo, possuindo ainda a capacidade de recarregar aquíferos, realizar a manutenção da qualidade da água, de reduzir as taxas de erosão, diminuindo assim os impactos causados pelas gotas de chuva e assoreamento dos rios realizando a manutenção da biodiversidade local.

As características dos sedimentos transportados por um rio dependem, principalmente, de fatores como a velocidade média da corrente (produto da declividade média), tipo de material fonte, clima e cobertura vegetal da bacia de drenagem, especialmente da mata ciliar imediatamente adjacente aos cursos de água. Estes fatores estão bastante interligados e em estudos geomorfológicos e hidrológicos se torna difícil a compreensão destas relações quando vários destes fatores variam espacial e temporalmente dentro da bacia de drenagem. Dessa forma quanto maior o estado de deterioração de uma mata ciliar menor sua eficiência em reter sedimentos, devido à sua menor capacidade de reduzir a velocidade de transporte de partículas, ou seja, menor controle hidrológico (CASTRO, CASTRO \& SOUZA, 2013).

\section{CONSIDERAÇÕES FINAIS}

O plano de integração das bacias do Rio São Francisco com o abjetivo de trazer segurança hídrica para diversas cidades no semiárido traz como consequência da obra, as grandes modificações no espaço natural.

Neste âmbito, as matas ciliares possuem grande importância por diversos fatores, tais como erosão e manutenção de nascentes, sua degradação pode causar o desaparecimento por completo da fauna dos leitos dos rios, compactação do solo, assoreamentos e afetar a qualidade da água oferecida para o abastecimento.

Pôde-se concluir que há maior predominância da classe Vegetação Herbácea e da classe Solo Exporto/Área Urbana no recorte, com valores de 12,2598 km² e 7,884 km², 
respectivamente. Neste sentido, a mata ciliar vem sendo sujeitada aos mais variados processo de antropização. Sendo assim, se faz necessário um reflorestamento de toda a área de margem do Rio Paraíba, dos canais abertos, e dos reservatórios, após o término das obras garantindo assim não só a qualidade da água, mas também a conservação do meio ambiente.

\section{REFERÊNCIAS}

AESA. Agência Executiva de Gestão das Águas do Estado da Paraíba. Proposta de Instituição do Comitê da Bacia Hidrográfica do Rio Paraíba. 2004. Disponível em:< http://site2.aesa.pb.gov.br/aesa/volumesAcudes.do?metodo=preparaUltimosVolumesPorMuni cipio >. Acessado em: Agosto de 2017

ALVEZ, T.L.B; LIMA, V.L.C; FARIAS, A.A. Impactos Ambientais no Rio Paraíba na Área Do Município de Caraúbas -PB: Região Contemplada Pela Integração com a Bacia Hidrográfica do Rio São Francisco. Caminhos de Geografia Uberlândia v. 13, n. 43 out/2012 p. 160-173. Disponível em:< http://www.seer.ufu.br/index.php/caminhosdegeografia/article/viewFile/16758/10524> . Acessado em: Agosto de 2017

ALVARES, C. A; STAPE, J. L; SENTELHAS, P. C; GONÇALVES, J. L. M; SPAROVEK, G. Map of Köppen climate classification for Brazil. Meteorologische Zeitschrift, Fast Track. 2013.

ARAÚJO, L. E; SANTOS, M.J; DUARTE, S.M; OLIVEIRA, E.M. Impactos Ambientais em Bacias Hidrográficas - Caso da Bacia do Rio Paraíba. TECNO-LógICA, Santa Cruz do Sul, v. 13, n. 2, p. 109-115, jul./dez. 2009

ANDRADE, J. A; NUNES, M. A. Acesso à água no Semiárido Brasileiro: uma análise das políticas públicas implementadas na região. Revista Espinhaço. Universidade Federal dos Vales do Jequitinhonha e Mucuri (UFVJM) - Diamantina, 2014. n. 2. 2014

BRITO, F. B. de. O conflito pelo uso da água do açude Epitácio Pessoa (Boqueirão) - PB. Dissertação de Mestrado pelo Programa de Pós-Graduação em Geografia - UFPB, João Pessoa-PB, 2008. 208 p.

BRASIL. LEI No 12.651, DE 25 DE MAIO DE 2012. Novo Código Florestal. Dispõe sobre a proteção da vegetação nativa; altera as Leis nos 6.938, de 31 de agosto de 1981, 9.393, de 19 de dezembro de 1996, e 11.428, de 22 de dezembro de 2006; revoga as Leis nos 4.771, de 15 de setembro de 1965, e 7.754, de 14 de abril de 1989, e a Medida Provisória no 2.166-67, de 24 de agosto de 2001; e dá outras providências. Disponível em:< http://www.planalto.gov.br/ccivil_03/_ato2011-2014/2012/lei/112651.htm>. Acessado em: Agosto de 2017.

CASTRO, M. N. CASTRO, R, N; SOUZA, P. C. A importância da mata ciliar no contexto da conservação do solo. Revista eletrônica de educação da faculdade araguaia: 230-241. v. 4, n. 4 (2013). 
CARVAlho, A. R. OliveIRA, M. V. C. Princípios básicos do saneamento do meio. 10ed. São Paulo: Editora Senac, 2010

CHAVES, A. Importância Da Mata Ciliar (Legislação) Na Proteção Dos Cursos Hídricos, Alternativas Para Sua Viabilização Em Pequenas Propriedades Rurais. Faculdade de Agronomia E Medicina Veterinária Programa De Pós-Graduação Em Agronomia. Seminário apresentado na disciplina "manejo e conservação Do solo e da água". Passo Fundo, novembro de 2009.

CONAMA. CONSELHO NACIONAL DO MEIO AMBIENTE. Resolução no 302 de 20 de março de 2002. Dispõe sobre os parâmetros, definições e limites de Áreas de Preservação Permanente de reservatórios artificiais e o regime de uso do entorno. Disponível em: < http://www.mma.gov.br>. Acesso em: setembro de 2017.

CHRISTOFOLETTI, A. Geomorfologia. 2 ed. São Paulo: Editora Blucher, 1980.

EMBRAPA. Empresa Brasileira de Pesquisa Agropecuária. Serviço Nacional de Levantamento e Conservação de Solos. Súmula da 10. Reunião Técnica de Levantamento de Solos. Rio de Janeiro, 1979. 83p. (EMBRAPA-SNLCS. Micelânea, 1)

EMBRAPA. Empresa Brasileira de Pesquisa Agropecuária. Sistema brasileiro de classificação de solos. 3ed. - Rio de Janeiro: EMBRAPA, 2013.

FRANCISCO, P. R. M; MEDEIROS, R. M; SANTOS, MATOS, R. M. Classificação Climática de Köppen e Thornthwaite para o Estado da Paraíba. Revista Brasileira de Geografia Física V. 08 N. 04 (2015) 1006-1016.

FERREIRA, S. B. S. Cobrança pelo Lançamento de Efluentes: Simulação para a Bacia do rio Paraíba - PB. Curso de Pós Graduação em Engenharia civil e Ambiental, Dissertação de Mestrado, UFCG. Campina Grande, 2006. 177p

FURTADO, A. V. B. D; SOUZA, de P. O. J. Mapeamento geomorfológico para a bacia do Alto Curso do Rio Paraíba de acordo com as normas do Manual Geomorfológico do IBGE. REGNE, Vol.2, N ${ }^{\circ}$ Especial.2016.

MARCUZZO, F. F. N; OLIVEIRA, N. de L; CARDOSO, M. R. D; TSCHIEDEL, A. F. Detalhamento Hidromorfológico da Bacia do Rio Paraíba. In: XI Simpósio de Recursos Hídricos do Nordeste, 2012, João Pessoa. Anais do XI Simpósio de Recursos Hídricos do Nordeste. Porto Alegre: ABRH, 2012. v. 1. p. 1-20.

MINISTERIO DA INTEGRAÇÃO. Programa de Conservação e Uso do Entorno e das Águas dos Reservatórios. PBA-14. Projeto São Francisco: Água a quem tem sede. Julho/ $2010 . \quad$ Disponível em: $<$ http://www.mi.gov.br/documents/10157/3675235/PBA14.pdf/d809db77-d51d-4c18-9398bfaf32ae577f > . Acessado em: Agosto de 2017

MINISTERIO DA INTEGRAÇÃO. Relatório de Impacto Ambiental - RIMA Projeto de Integração do Rio São Francisco com Bacias Hidrográficas do Nordeste Setentrional. Julho/2004 em: $<$ http://www.integracao.gov.br/documents/10157/3678963/Rima+- 
+Relat\%C3\%B3rio+de+Impacto+Ambiental.pdf/4324863d-cbff-4522-9bd0-eab9d34b8fe2 >. Acessado em: Agosto de 2017.

MORAIS, R. D; SILVA, J. B; ARAUJO, A. R. Análise Espacial das Margens do Reservatório de Água Epitácio Pessoa - PB: Reflexões Sobre a Capacidade De Armazenamento. Revista de Estudos Ambientais (Cessou em 2007. Cont. ISSN 1983-1501 Revista de Estudos Ambientais (Online)), v. 16, p. 6-15, 2014.

MOURA. D. C. Meio ambiente no Brasil. In: FREIRE, N.C.F; MOURA, D.C; SILVA, J.B; MOURA, S.S. Mapeamento $\mathbf{E}$ Análise Espectro-Temporal Das Unidades De Conservação De Proteção Integral Da Administração Federal No Bioma Caatinga. Recife, 2015.

PONZONI, F. J.; SHIMABUKURO, Y. E., 2007. Sensoriamento remoto aplicado ao estudo da vegetação, 1. ed., Parêntese, São José dos Campos.

SOARES, E. Seca no Nordeste e a transposição do rio São Francisco. Geografias, Belo Horizonte, 01 de Julho - 31 de Dezembro de 2013. Vol. 9, nº 2, 2013

SUASSUNA, J. Transposição do Rio São Francisco e a reeleição do presidente Lula. Carta Maior, 9 nov. 2004.

Recebido em: 28/03/2019

Aceito para publicação em: 30/08/2019 